\title{
CHEMICAL AND MICROBIOLOGICAL QUALITY DURING STORAGE: HALF-DRIED SALTED ROUND SCAD (DECAPTERUS MARUADSI)
}

\author{
Jariya Sukjuntra ${ }^{\circledR}$ and Khoirunisa Malumu ${ }^{1}$
}

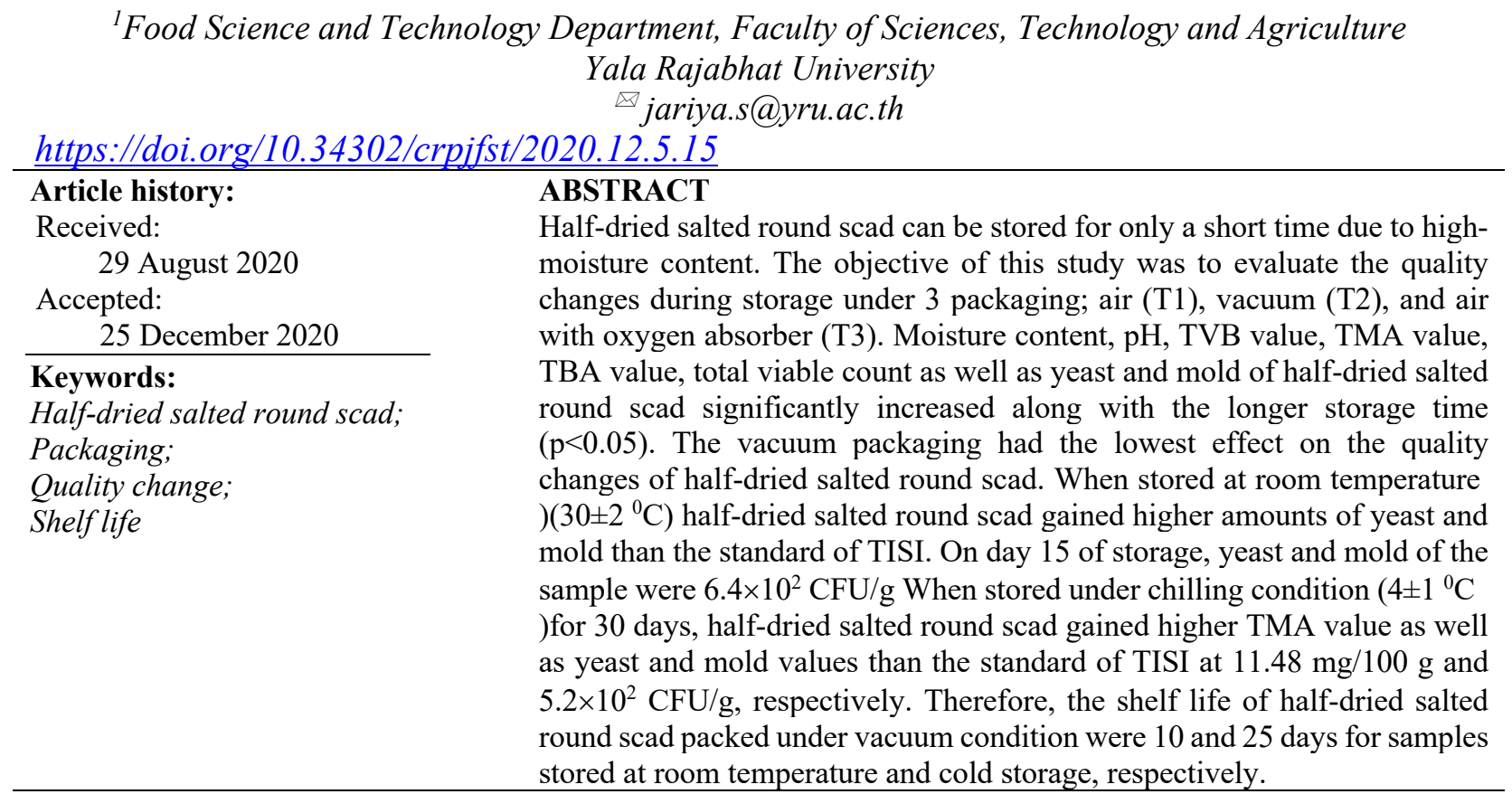

\section{Introduction}

Half-dried salted fish is one of the most popular traditional products. It has high nutrition, soft texture, unique taste and flavor. It is also a great source of high protein which contains all essential amino acid. Half-dried salted fish is different from normal salted fish in term of the moisture and salt content in their final products. For salted fish, the $\mathrm{a}_{\mathrm{w}}$ is usually under 0.85 and the salt content is over $10 \%$ (Thai industrial standards institute; TISI. 312/2006). For half-dried salted fish, it is a high-moisture content product and the salt content is less than $10 \%$ (light cure). Moreover, the main characteristics of salted fish affecting consumer buying decision are light salty taste, special flavor without stinky smell and absence of fish bone (Sukjuntra, 2014). Due to the lower salt content in half-dried salted fish, food spoilage bacteria and food-born pathogenic bacteria can easily grow in this product which leads to the product's shorter shelf life. Nowadays, snakehead fish and sepat siam, freshwater fish, are commonly used as half-dried salted fish products.

Among the sea water fish species, the round scad (Decapterus maruadsi), a fatty fish, has been chosen as the raw material for half-dried salted fish production because of its appearance and taste which are better than those of lean fish. Half-dried salted round scad also has soft texture during to the low salt added which leads to no denaturation of fish protein (Ana and Rui, 2010; Magnus and Turid, 2012). Moreover, the halfdried salted round scad is healthy food for consumer, due to its low salt content (Nuwanthi 
et al., 2016). For the above reasons, half-dried salted round scad is widely consumed and available in local markets especially in the lower southern part of Thailand. However, the supply of half-dried salted round scad are still low because of its traditional sun drying process with the lack of proper technology to improve the production. Furthermore, during the rainy season, the half-dried salted round scad is not available in the market because of the sun drying process. The factors determining the half-dried salted round scad product's quality are raw material quality, salt quantity and quality, good and hygienic processing, packaging and suitable storage condition (Koral, 2013; Lorentzen et al., 2016).

In order to improve the quality and extend the shelf life of half-dried salted round scad, appropriate packaging is crucial. Nowadays, there are many studies on various packaging for shelf life extension of fish and fishery products including vacuum packaging, oxygen absorber, moisture absorber and modified atmosphere packaging (Mohan et al., 2009). The vacuum packaging is a widely used method in the market as its efficiency and low cost. This packaging can prevent oxidative rancidity, and inhibition of the growth of aerobic bacteria and spoilage bacteria, especially Macrococcus and Aeromonas (Masniyom, 2011; Renato, 2012; Pinar, 2013; Kumar and Ganguly, 2014).

Appropriate packaging is able to increase the shelf life of half-dried salted round scad, increase the marketing competition capacity and also enhance reputation of this product. Thus, the objectives of this study were to select the practical packaging methods conforming to entrepreneur in the lower southern part of Thailand for increasing the shelf life of halfdried salted round scad. Samples were stored at room temperature $\left(30 \pm 2{ }^{\circ} \mathrm{C}\right)$ and at cold storage $\left(4 \pm 1{ }^{\circ} \mathrm{C}\right)$ for 15 and 30 days, respectively. The changes of physical, chemical and microbiological properties of sample were determined at 5 days interval.

\section{Materials and methods \\ 2.1. Round Scad Preparation}

The A grade to low B grade of round scad (Decapterus maruadsi) (8-12 fish $/ \mathrm{kg}$ ) according to EU grade was beheaded, gutted, butterflied and deboned. After that, the butterflied fish was soaked in $6 \%(\mathrm{w} / \mathrm{v})$ brine solution for $20 \mathrm{~min}$ at a ratio of 1:1 (fish: brine solution). Then the soaked fish was dried in a solar dryer (Electricity Generating Authority of Thailand; SD-050 model) until $\mathrm{a}_{\mathrm{w}}$ of fish fresh ranged from 0.85 to 0.90 . Then, the fish was stored in low density polyethylene bags (LDPE) under 3 types of packaging; air (T1), vacuum (T2) (VAC-STAR S220, Switzerland), and air with an iron-based oxygen absorbent (T3) which utilized in sachet form and meant to be used in products with maximum water activity $\left(a_{\mathrm{w}}\right)$ of 0.85 and minimum oxygen absorption of $300 \mathrm{ml}$. Afterwards, half-dried salted round scad was stored at room temperature $\left(30 \pm 2{ }^{\circ} \mathrm{C}\right)$ for 15 days, chilled in condition $\left(4 \pm 1{ }^{\circ} \mathrm{C}\right)$ for 30 days, and sampled every 5 days for evaluation of the shelf life.

\subsection{Quality Analysis Chemical Analysis}

The $\mathrm{pH}$ measurement was determined by homogenizing samples with distilled water at ratio of 1:5 (w/v), as described by Manthey et al. (1988). First, $\mathrm{pH}$ values of homogenate were measured by using a $\mathrm{pH}$ meter (Schott, model $\mathrm{G}$ 0840). Also, moisture content was determined using an oven method (Association of official Analytical Chemists, 2000). Then, salt content was analyzed using AOAC method. Moreover, the Total volatile base nitrogen (TVB) and Trimethylamine (TMA) value were analyzed using conway unit (Siang and Kim, 1992) by grinding $2 \mathrm{~g}$ of grounded sample with $8 \mathrm{ml}$ of $4 \%(\mathrm{w} / \mathrm{v})$ Trichloroacetic acid (TCA) in a mortar and then filtrating the texture through filter paper (Whatman No. 41). The volume of filtrate was adjusted to $10 \mathrm{ml}$ using $4 \%(\mathrm{w} / \mathrm{v})$ TCA. After that, $1 \mathrm{ml}$ of sample extract was pipetted into outer ring of conway unit. Then $1 \mathrm{ml}$ of inner ring solution (boric acid in ethanol) was 
pipetted into inner ring of conway unit. Subsequently, $1 \mathrm{ml}$ of saturated $\mathrm{K}_{2} \mathrm{CO}_{3}$ was pipetted into another side outer ring of conway unit. Moreover, The Trimethylamine value was carried out according to the methodology of TVB with a slightly different. After the sample extraction, the sample extract, inner ring solution and saturated $\mathrm{K}_{2} \mathrm{CO}_{3}$ were added into conway unit. Then, $1 \mathrm{ml}$ of $10 \% \quad(\mathrm{v} / \mathrm{v})$ Formaldehyde solution was pipetted into the sample extract portion. After conway unit was closed, both of the TVB and TMA portion were gently mixed and incubated at $37{ }^{\circ} \mathrm{C}$ for $45-60$ min, respectively. After incubation, the inner ring solution was titrated with $0.02 \mathrm{~N}$ Hydrochloric acid $(\mathrm{HCl})$ using micro-burette until its green color turned pink color. The blank test was done using $1 \mathrm{ml}$ of $4 \%(\mathrm{w} / \mathrm{v})$ TCA instead of sample extract. TVB and TMA value was calculated as follows.

$$
\begin{aligned}
& \text { TVB }(\mathrm{mg} / 100 \mathrm{mg}) \\
& =\frac{\mathrm{N} \times 14 \times(\mathrm{A}-\mathrm{C}) \times 10 \times 100}{\mathrm{~W}}
\end{aligned}
$$

$$
\begin{aligned}
& \text { TMA }(\mathrm{mg} / 100 \mathrm{mg}) \\
& =\frac{\mathrm{N} \times 14 \times(\mathrm{B}-\mathrm{C}) \times 10 \times 100}{\mathrm{~W}}
\end{aligned}
$$

Where; $\mathrm{N}=$ Normality of $\mathrm{HCl}$

$$
\mathrm{A}=\text { Titration volume }(\mathrm{ml}) \text { of } 0.02 \mathrm{~N} \mathrm{HCl}
$$

for sample extract (TVB)

$$
\mathrm{B}=\text { Titration volume }(\mathrm{ml}) \text { of } 0.02 \mathrm{~N} \mathrm{HCl}
$$
for blank

$$
\mathrm{C}=\text { Titration volume }(\mathrm{ml}) \text { of } 0.02 \mathrm{~N} \mathrm{HCl}
$$

for sample extract (TMA)

$$
\mathrm{W}=\text { Weight of sample }(\mathrm{g})
$$

Besides, the Thiobarbituric acid (TBA) value was determined by a distillation method (Egan et al., 1981). First, $10 \mathrm{~g}$ of sample was homogenized with $50 \mathrm{ml}$ of distilled water, then adding $4 \mathrm{~N} \mathrm{HCl}$. After that, the mixture was heated with steam distillation until $50 \mathrm{ml}$ of distillate was collected. A $5 \mathrm{ml}$ of distillate was mixed with $5 \mathrm{ml}$ of TBA reagent and incubated in boiling water for $35 \mathrm{~min}$. After cooling, the absorbance of the solution was read at $538 \mathrm{~nm}$.
The blank test was done using distilled water instead of sample. TBA value was calculated as follows.

$$
\mathrm{TBA}(\mathrm{mg} \mathrm{MAD} / \mathrm{kg})=7.8 \times \mathrm{A}
$$

Where A; Absorbance of the solution was read at $538 \mathrm{~nm}$

\section{Microbiological analysis}

A microbiological analysis was carried out by examining total plate count (TPC) as well as yeast and mold according to the technique recommended by Bacteriological Analytical Manual (2001). Staphylococcus aureus and Escherichia coli MPN (3 tubes method) were analyzed using the technique recommended by Bacteriological Analytical Manual (2002).

\subsection{Statistical analysis}

The experiment was carried out with a completely randomized design (CRD). Data obtained from chemical parameters were analyzed by analysis of variance (ANOVA) using computer software. Duncan's New Multiple Range Test (DMRT) was used to compare the means with a significance level of $95 \%$.

\section{Results and discussions \\ 3.1. Chemical quality changes pH value}

The result of this study indicated that the storage at room temperature $\left(30 \pm 2{ }^{0} \mathrm{C}\right)$ had affected the $\mathrm{pH}$ value of half-dried salted round scad. $\mathrm{pH}$ values of the samples significantly increased with the increasing storage time. All 3 samples packed in air (T1), vacuum (T2) and air with oxygen absorber (T3) had the $\mathrm{pH}$ values of 5.98 on day 0 and their $\mathrm{pH}$ values reached to $6.73,6.63$ and 6.74 at the end of storage (day $15)$, respectively $(\mathrm{p}>0.05)$ (data is not shown). Corresponding to the result of Farid et al. (2014) who found that the $\mathrm{pH}$ values of 2 dried salted snake-head fish products stored at room temperature $\left(27-30{ }^{\circ} \mathrm{C}\right)$ increased from 6.3 and 6.5 (day 0) to 8.1 and 7.9 (day 150). For halfdried salted round scad stored under chilling 
condition ) $4 \pm 1{ }^{0} \mathrm{C}$ (in the present study, the $\mathrm{pH}$ value used for indicating fish quality of all 3 samples slightly increased with the longer storage time $(\mathrm{p}>0.05)$ (data is not shown). During the post-mortem period, the decomposition of nitrogenous compounds occured by microorganisms and formed volatile amines, ammonia, amine and trimetylamineoxide, which are basic alkalinity compounds affecting on the increasing $\mathrm{pH}$ value of fish (Farid et al., 2014; Frangos et al., 2010; Lorentzen et al., 2015). Thus, the storage of dried salted round scad in chilling temperature is able to retard microorganism activities leading to the minor changes in $\mathrm{pH}$.

\section{Moisture content}

Moisture content of half-dried salted round scad stored at room temperature significantly increased with the longer storage time $(p<0.05)$. The moisture content of samples packed in air (T1), vacuum (T2) and air with oxygen absorber (T3) were $54.93 \%$ on day 0 and increased to $61.27,57.43$ and $58.39 \%$ on day 15 of storage, respectively (data not shown). From these results, the moisture content of the sample stored in non-vacuum packaging (T1) was higher than other packaging. $(p<0.05)$. The increase in moisture content of half-dried salted round scad was due to the moisture absorption of products an environment with from higher humidity (Farid et al., 2014). This is in agreement with the study of Adenike (2014), Ikutegbe \& Sikoki (2014) and Reza et al. (2015) who found that moisture content of smoked catfish, dried chela (Laubuka dadiburjori) and smoked long-neck croaker (Pseudotolithus typus) increased with increasing the storage time $(\mathrm{p}<0.05)$. The moisture content of smoked catfish increased from $62.52 \%$ to $69.13 \%$ (on week 6), the moisture content of dried chela increased from $5.88 \%$ to $10.83 \%$ (on day 30 ) and the moisture content of smoked long-neck croaker increased from $10.90 \%$ to $13.10 \%$ (on week 4 ).
The result of half-dried salted round scad stored in chilling condition indicates that the changes of moisture content in the final products were lower than those stored at room temperature. The moisture content of sample stored in air (T1), vacuum (T2) and air with oxygen absorber (T3) packaging was $54.93 \%$ on day 0 and increased to $59.87,58.68$ and $58.77 \%$ on day 30 of storage, respectively (data not shown). This was because dried fish slowly reabsorbed moisture from the relatively humidity condition like a chilling storage. However, moisture content of half-dried salted round scad is a factor of shelf life because it affects microbial growth and chemical changes including oxidation reaction and browning reaction. Normally, high moisture food is highly perishable.

\section{Salt content}

The salt content analysis of half-dried salted round scad stored at room temperature showed that the salt contents of samples packed in air (T1), vacuum (T2) packaging significantly decreased on day 5 of storage with a constant value on day 5-15 of storage. Whereas, the salt content of samples packed in air with oxygen absorber (T3) was stable during 15 days of storage $(p>0.05)$. On day 15 , salt content of 3 half-dried salted round scad were 3.38, 3.51 and $3.83 \%$ respectively (Figure $1(\mathrm{a})$ ). In refrigerator storage $\left(4 \pm 1{ }^{0} \mathrm{C}\right)$ condition, salt contents of all 3 samples varied with increasing storage time and showed the difference of salt content on day 15 of storage (Figure 1(b)). It can be seen that a decrease in salt content of products corresponded to the increased moisture content similar to Oyarekua (2014) who found that the salt content of smoked catfish slice decreased with an increase in storage time $(\mathrm{p}<0.05)$. The salt content decrease from $16.66 \%$ to $12.05 \%$ on week 6 of storage. In order to increase the shelf life of salted fish with 55-58\% moisture content, Loannis (2014) demonstrated that salt content of salted fish should be in the range of $18-21 \%$. From this study, high moisture content with 0.85 -0.90 of $\mathrm{a}_{\mathrm{w}}$ and low salt content (less than $5 \%$ ) 
in half-dried salted round scad promoted the growth of microorganism and has effects the on short shelf life of this product.

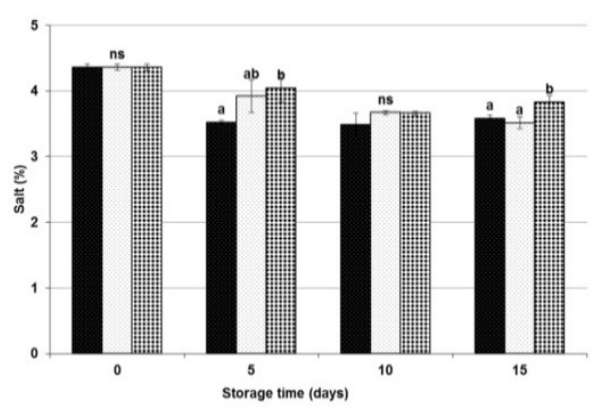

(a)

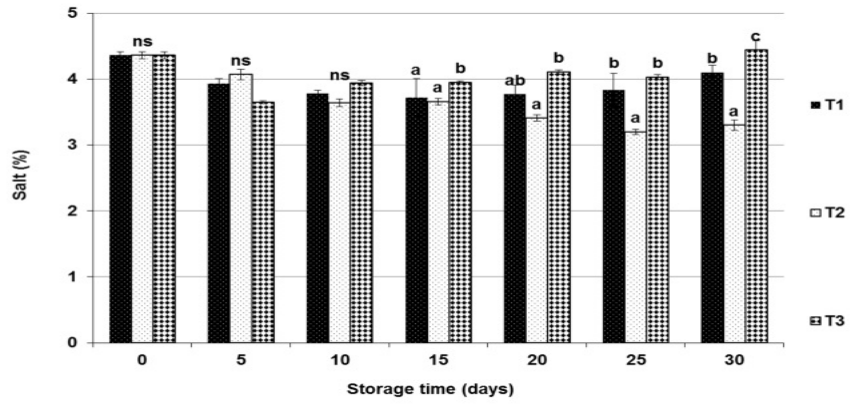

(b)

Figure 1. Salt content of half-dried salted round scad stored at (a) room temperature and (b) chilling condition under air (T1), vacuum (T2) and air with oxygen absorber (T3) packaging

\section{Total volatile base nitrogen (TVB)}

The TVB value in half-dried salted round scad stored at room temperature significantly increased along with the longer storage time $(p<0.05)$. After 15 days of storage, TVB value in sample packed by vacuum packaging (T2) was lowest at $32.47 \mathrm{mg} / 100$ $\mathrm{g}$ as shown in Figure 2(a). Moreover, the TVB value in half-dried salted round scad stored in refrigerator significantly increased with the longer storage time $(p<0.05)$. The results showed that TVB value increased from an initial value of $10.99 \mathrm{mg} / 100 \mathrm{~g}$ on the day 0 to $24.24,23.33$ and $25.92 \mathrm{mg} / 100 \mathrm{~g}$ on the day 30 of storage in T1, T2 and T3, respectively (Figure 2(b)). Similar results were reported by Latifa et al. (2014) about refrigerated storage $\left(4^{0} \mathrm{C}\right)$ of smoke-dried chapila (Gudusia chapra) that TVB value increased from 8.84 to $20.04 \mathrm{mg} / 100 \mathrm{~g}$ after 9 months of storage. In addition, Farid et al. (2014) reported that TVB value in sun-dried salted shoal fish at room temperature (27-30 $\left.{ }^{0} \mathrm{C}\right)$ storage increased from 4.89 to 30.86 $\mathrm{mg} / 100 \mathrm{~g}$ after 5 months of storage. TVB is a group of biogenic amine produced by bacteria including ammonia, dimethylamine and trimethylamine. This increasing values correspond to the increasing fish spoilage; therefore, TVB is used for indicating the spoilage of fish and the consumer acceptance. The acceptability level of TVB in salted fish is $35-40 \mathrm{mg} / 100 \mathrm{~g}$. Above that level, fish products are considered unsuitable for human consumption (Bilgin and Degirmenci, 2019). 


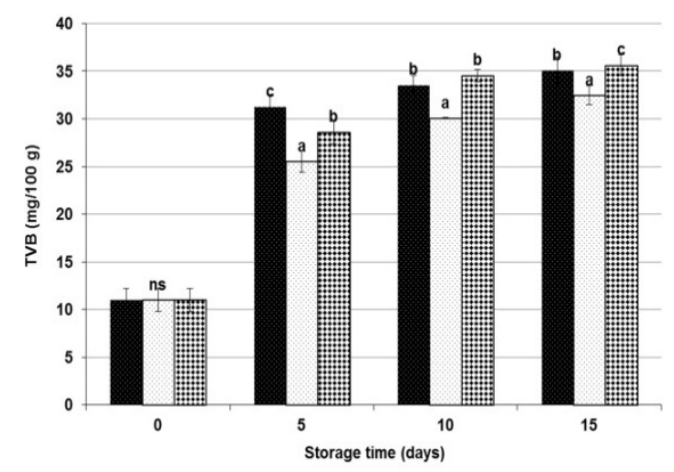

(a)

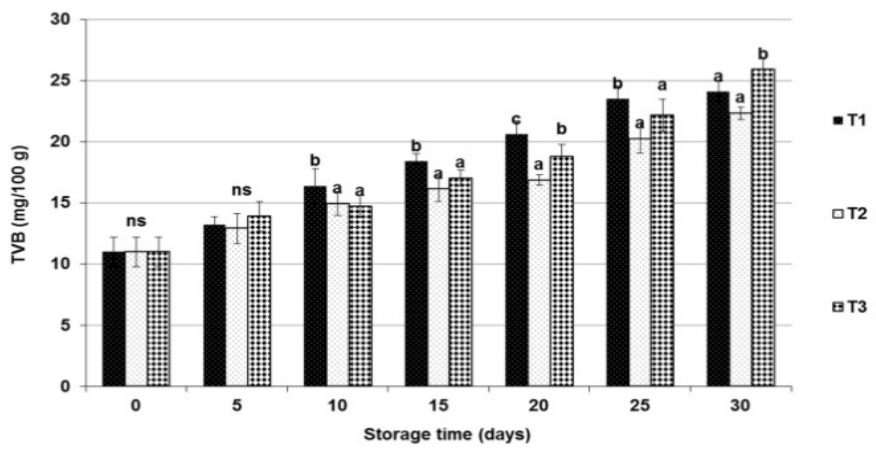

(b)

Figure 2. Total volatile base (TVB) values of half-dried salted round scad stored at (a) room temperature and (b) chilling temperature under air (T1), vacuum (T2) and air with oxygen absorber (T3) packaging

The results of this study also showed that the different packaging effects on the growth of spoilage microorganism in fish products. Sample stored in air packaging had the highest spoilage. Whereas, sample stored in vacuum condition was not able to inhibit the growth of aerobic bacteria (Fuentes et al., 2011). In addition, the storage under chilling condition was able to prevent the growth of microorganism and enhance the shelf life of product. This study suggested that samples packed in air (T1), and air with oxygen absorber (T3) conditions and stored at room temperature had TVB value over the limitation of $35 \mathrm{mg} / 100 \mathrm{~g}$. on day 15 of storage at 35.09 and $35.61 \mathrm{mg} / 100 \mathrm{~g}$, respectively. On the contrary, TVB values of all 3 samples stored at chilling condition were within the standard of $35 \mathrm{mg} / 100 \mathrm{~g}$ TVB during the storage time. These results indicated that the quality of half-dried salted round scad stored at chilled condition was acceptable.

\section{Trimethylamine (TMA)}

The TMA value of half-dried salted round scad stored at room temperature significantly increased along with the longer storage time $(p<0.05)$. After 15 days of storage, TMA value of sample packed by vacuum packaging (T2) was lowest at 7.42 $\mathrm{mg} / 100 \mathrm{~g}$ (Figure 3(a)). Likewise, the values of half-dried salted round scad stored in refrigerator significantly increased along with the longer storage time $(p<0.05)$. The results showed that TMA value increased from an initial value of $2.81 \mathrm{mg} / 100 \mathrm{~g}$ on the day 0 to $12.23,11.48$ and $12.57 \mathrm{mg} / 100 \mathrm{~g}$ on the day 30 of storage in T1, T2 and T3, respectively (Figure 3(b)). Similar results have been report by Bilgin and Degirmenci (2019) during refrigerated storage $\left(4 \pm 1^{0} \mathrm{C}\right)$ of hot-smoked meager (Argyrosomus regius). TMA value increased from 1.35 to 5.57 $\mathrm{mg} / 100 \mathrm{~g}$ after 56 days of storage. TMA was derived from non-protein nitrogen compounds (trimethylamine oxide; TMAO) in fish by trimethylamine oxide reductase and degraded to TMA, dimethylamine (DMA), formaldehyde (FA) and ammonia (Benjakul et al., 1997). Thus, the increasing TMA value stimulates the increase of TVB value. The fresh fish normally has TMA value of 10-15 $\mathrm{mg} / 100 \mathrm{~g}$ (Venugopal, 2006). TMA value of sample packed in air (T1) condition and stored at room temperature was $>10 \mathrm{mg} / 100$ 
g on day 15 of storage. Whereas, TMA value of samples stored under chilling condition was $>10 \mathrm{mg} / 100 \mathrm{~g}$ on day 25,30 and 20 of storage for samples packed in air (T1), vacuum (T2) and air with oxygen absorber
(T3) conditions, respectively. Therefore, the vacuum packaging of half-dried salted round scad is the best packaging in slowing down the growth of aerobic bacteria.

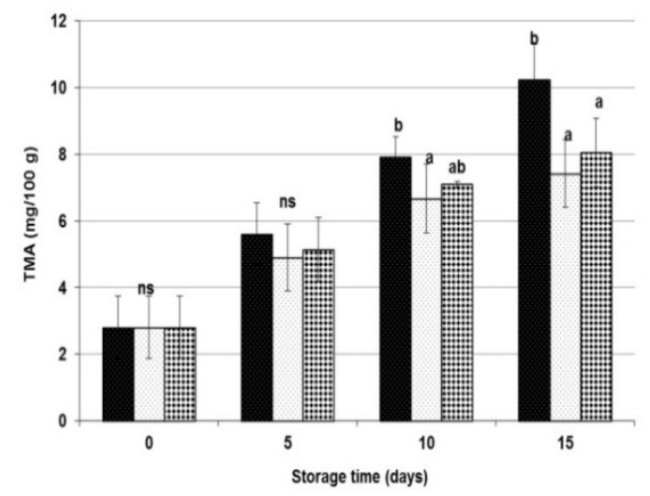

(a)

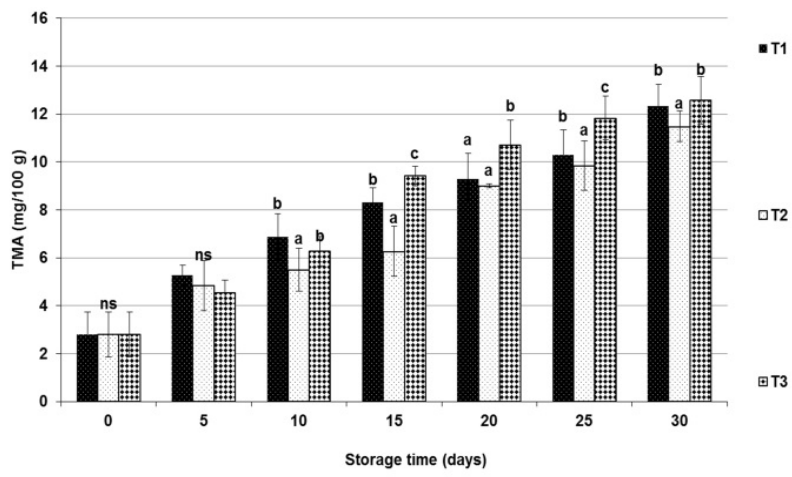

(b)

Figure 3. Trimethylamine values (TMA) of half-dried salted round scad stored at (a) room temperature and (b) chilling condition under air (T1), vacuum (T2) and air with oxygen absorber (T3) packaging

\section{Thiobarbituric acid (TBA)}

The TBA value of half-dried salted round scad stored at room temperature significantly increased along with the longer storage time $(\mathrm{p}<0.05)$. The sample packed under vacuum condition (T2) had the lowest increasing TBA value with an initial of $0.39 \mathrm{mg}$ $\mathrm{MAD} / \mathrm{kg}$ and increased to $1.89 \mathrm{mg} \mathrm{MAD} / \mathrm{kg}$ on day 15 of storage. The TBA value of samples stored under chilling condition significantly increased with an increased storage time $(\mathrm{p}<0.05)$ with $2.45 \mathrm{mg} \mathrm{MAD} / \mathrm{kg}$ on day 30 of storage. The increase in TBA led to the oxidation reaction of products and degraded to malonaldehyde. The increased TBA of half-dried salted round scad also has effects on food spoilage, nutrition and consumer health safety. Comparing to striped snaked-head fish, catfish and snapper queen fish, fatty fish with highly unsaturated fat, such as round scad, tend to have more oxidation reaction (Oyarekua, 2014; Lohalaksanadech and Sujarit, 2016). Moreover, Oxygen was a factor leading to oxidation reaction. So half-dried salted round scad packed in vacuum condition had the lowest TBA value according to the result of Antonios and Michael (2007) who found that the packaging of mackerel (Scomber japonicas) under vacuum condition resulted in the lowest increase of TBA when comparing to modified atmosphere packaging and air packaging. However, the limitation of TBA in fish was lower than 8 $\mathrm{mg}$ MAD $/ \mathrm{kg}$ and fresh fish has $<3 \mathrm{mg}$ MAD $/ \mathrm{kg}$. Among fishery products, the TBA of 3-4 $\mathrm{mg} \mathrm{MAD} / \mathrm{kg}$ indicates the low quality product. When considering the TBA in dried salted round scad, the results indicated that half-dried salted fish still had acceptable levels of TBA even at the end of storage time. 


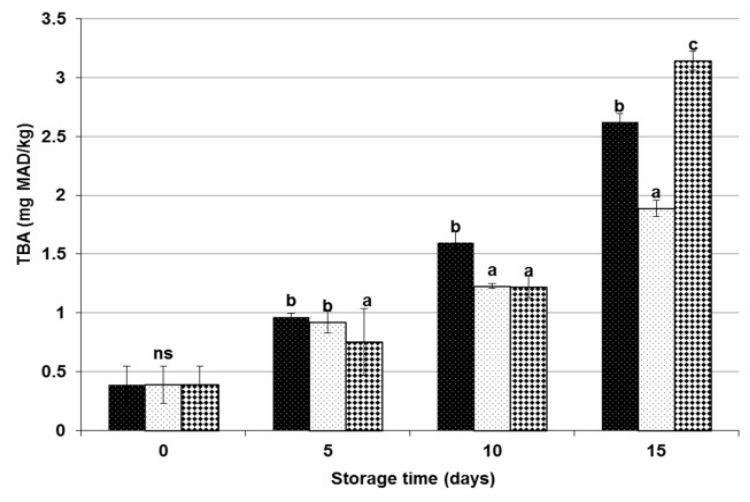

(a)

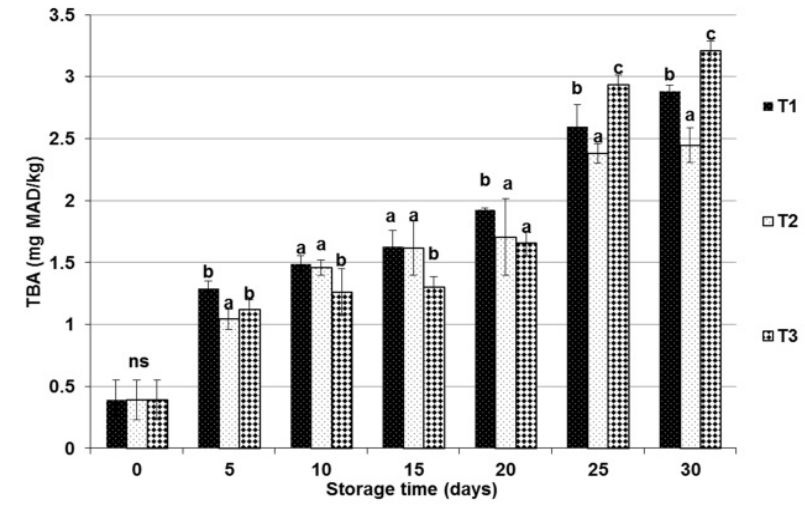

(b)

Figure 4. Thiobarbituric acid values (TBA) of half-dried d salted round scad stored at (a) room temperature and (b) chilling condition of air (T1), vacuum (T2) and air with oxygen absorber (T3) packaging

\subsection{Microbiological quality changes Total plate count (TPC)}

An initial number of TPC in half-dried salted round scad was $1.6 \times 10^{2} \mathrm{CFU} / \mathrm{g}$ in room temperature storage, and reached $2.9 \times 10^{6}, 2.2 \times 10^{5}$ and $3.0 \times 10^{5} \mathrm{CFU} / \mathrm{g}$ on day 15 of storage for 3 samples packaging, respectively. Whereas, The TPC in samples stored in refrigerator reached $3.3 \times 10^{6}$, $2.0 \times 10^{5}$ and $3.5 \times 10^{5} \mathrm{CFU} / \mathrm{g}$ on day 30 of storage for samples packed in air (T1), vacuum (T2) and air with oxygen absorber (T3) packaging respectively (Table 1-2). The highest numbers of TPC were observed in dried salted round scad packed in air packaging and stored at room temperature and refrigerator. Meanwhile, the lowest number of TPC was observed in samples packed in vacuum packaging and stored at room temperature and refrigerator. Even though, the Thai Community Products Standards does not define the TPC in sundried fish (Thai industrial standards institute; TISI. 298/2006), the TPC is still necessary for indicating the spoilage of products, especially the high moisture and low salt content products. If salt content in salted products is above $10 \%$ and their moisture content is below $40 \%$, toxigenic-halophilic amine which forms bacteria will be inhibited (Koral et al., 2013).

\section{Escherichia coli and Staphylococcus aureus}

Escherichia coli (E. coli) and Staphylococcus aureus (S. aureus) of all 3 half-dried salted round scad packaging stored at room temperature and refrigerator were less than Thai Community Products Standards for sun-dried fish. The standard limitation of $E$. coli is less than $50 \mathrm{MPN} / \mathrm{g}$ and $S$. aureus is less than $200 \mathrm{CFU} / \mathrm{g}$ (data not shown). E. coli is used as a hygienic indicator for food processing plants, indicating the fecal contamination from animals and humans. $S$. aureus is a toxigenic microorganism which is harmful to consumers 
Table 1. The microbial count of half-dried salted round scad stored at room temperature $\left(30 \pm 2^{\circ} \mathrm{C}\right)$

\begin{tabular}{|c|c|c|c|c|c|c|}
\hline $\begin{array}{c}\text { Storage } \\
\text { time } \\
\text { (days) }\end{array}$ & \multicolumn{3}{|c|}{ Total plate count (CFU/g) } & \multicolumn{3}{c|}{ Yeast and mold (CFU/g) } \\
\cline { 2 - 7 } & $\begin{array}{c}\text { Air } \\
(\mathrm{T} 1)\end{array}$ & $\begin{array}{c}\text { Vacuum } \\
(\mathrm{T} 2)\end{array}$ & $\begin{array}{c}\text { Absorber } \\
(\mathrm{T} 3)\end{array}$ & $\begin{array}{c}\text { Air } \\
(\mathrm{T} 1)\end{array}$ & $\begin{array}{c}\text { vacuum } \\
(\mathrm{T} 2)\end{array}$ & $\begin{array}{c}\text { absorber } \\
(\mathrm{T} 3)\end{array}$ \\
\hline $\mathbf{0}$ & $1.6 \times 10^{2}$ & $1.6 \times 10^{2}$ & $1.6 \times 10^{2}$ & $2.0 \times 10^{2}$ & $2.0 \times 10^{2}$ & $2.0 \times 10^{2}$ \\
\hline $\mathbf{5}$ & $1.9 \times 10^{3}$ & $1.8 \times 10^{3}$ & $1.9 \times 10^{3}$ & $1.6 \times 10^{2}$ & $1.7 \times 10^{2}$ & $2.6 \times 10^{2}$ \\
\hline $\mathbf{1 0}$ & $2.0 \times 10^{6}$ & $1.3 \times 10^{4}$ & $2.2 \times 10^{4}$ & $2.6 \times 10^{2}$ & $1.5 \times 10^{2}$ & $1.6 \times 10^{2}$ \\
\hline $\mathbf{1 5}$ & $2.9 \times 10^{5}$ & $2.2 \times 10^{5}$ & $3.0 \times 15^{5}$ & $2.7 \times 10^{3}$ & $6.4 \times 10^{2}$ & $5.4 \times 10^{2}$ \\
\hline
\end{tabular}

Table 2. The microbial count of half-dried salted round scad stored in chill condition $\left(4 \pm 1^{\circ} \mathrm{C}\right)$

\begin{tabular}{|c|c|c|c|c|c|c|}
\hline \multirow{2}{*}{$\begin{array}{c}\text { Storage } \\
\text { time } \\
\text { (days) }\end{array}$} & \multicolumn{2}{|c|}{ Total plate count (CFU/g) } & \multicolumn{2}{c|}{ Yeast and mold (CFU/g) } \\
\cline { 2 - 6 } & $\begin{array}{c}\text { Air } \\
(\mathrm{T} 1)\end{array}$ & $\begin{array}{c}\text { Vacuum } \\
(\mathrm{T} 2)\end{array}$ & $\begin{array}{c}\text { absorber } \\
(\mathrm{T} 3)\end{array}$ & $\begin{array}{c}\text { Air } \\
(\mathrm{T} 1)\end{array}$ & $\begin{array}{c}\text { vacuum } \\
(\mathrm{T} 2)\end{array}$ & $\begin{array}{c}\text { absorber } \\
(\mathrm{T} 3)\end{array}$ \\
\hline 0 & $1.6 \times 10^{2}$ & $1.6 \times 10^{2}$ & $1.6 \times \times 10^{2}$ & $2.0 \times 10^{2}$ & $2.0 \times 10^{2}$ & $2.0 \times 10^{2}$ \\
\hline 5 & $1.3 \times 10^{3}$ & $1.4 \times 10^{3}$ & $1.8 \times 10^{3}$ & $1.9 \times 10^{2}$ & $1.8 \times 10^{2}$ & $2.5 \times 10^{2}$ \\
\hline 10 & $1.1 \times 10^{4}$ & $1.6 \times 10^{4}$ & $2.3 \times 10^{4}$ & $1.7 \times 10^{2}$ & $2.0 \times 10^{2}$ & $3.0 \times 10^{2}$ \\
\hline 15 & $2.4 \times 10^{4}$ & $1.9 \times 10^{4}$ & $2.8 \times 10^{4}$ & $2.9 \times 10^{2}$ & $3.4 \times 10^{2}$ & $2.1 \times 10^{2}$ \\
\hline 20 & $2.9 \times 10^{5}$ & $2.2 \times 10^{4}$ & $3.0 \times 10^{4}$ & $2.7 \times 10^{2}$ & $3.7 \times 10^{2}$ & $2.3 \times 10^{2}$ \\
\hline 25 & $3.1 \times 10^{6}$ & $2.7 \times 10^{4}$ & $3.2 \times 10^{4}$ & $6.9 \times 10^{2}$ & $3.5 \times 10^{2}$ & $5.5 \times 10^{2}$ \\
\hline 30 & $3.3 \times 10^{6}$ & $2.0 \times 10^{5}$ & $3.5 \times 10^{5}$ & $7.2 \times 10^{2}$ & $5.2 \times 10^{2}$ & $5.1 \times 10^{2}$ \\
\hline
\end{tabular}

\section{Conclusions}

Half-dried salted round scad stored in vacuum packaging showed the lowest quality changes comparing to samples stored in air and air with oxygen absorbers packaging. The chilling storage was able to increase the shelf life of half-dried salted round scad. It can be concluded that, the shelf life of halfdried salted round scad packed in air condition was 5 and 10 days length when stored at room temperature and chilled condition, respectively. On the other hand, the shelf life of half-dried salted round scad stored in vacuum package was 10 and 25 days under room temperature and chilled condition, respectively. For the greater amount of half-dried salted round scad as an industrial product, food additives are recommended to extend the product's shelf life.

\section{References}

Adenike, M. O. (2014). The Effect of different processing methods on the nutritional quality and microbiological status of cat fish (Clarias lezera). Journal 
of Food Processing \& Technology, 05, 17.

Ana, B., \& Rui, C. (2010). Influence of brine salting prior to pickle salting in the manufacturing of various salted-dried fish species. Journal of Food Engineering, 100(3), 490-495.

Antonios, E. G., \& Michael, G. K. (2007). Effect of modified atmosphere packaging and vacuum packaging on the shelf-life of refrigerated chub mackerel (Scomber japonicus): biochemical and sensory attributes. European Food Research and Technology, 224(5), 545553.

Association of Official Analytical ChemistsAOAC. (2000). Official methods of analysis of association of official chemists (17th ed). Arlington: AOAC.

Bacteriological Analytical Manual-BAM. (2001). Bacteriological Analytical Munual Chapter 3: Total Plate Count. In FDA Bacteriological Analytical Munual (Online).

Bacteriological Analytical Manual-BAM. (2001). Bacteriological Analytical Munual Chapter 18: Yeasts Molds and Microtoxins. In FDA Bacteriological Analytical Munual (Online).

Bacteriological Analytical Manual-BAM. (2002). Bacteriological Analytical Munual Chapter 4: Enumeration of Escherichia coli and the Coliform Bacteria. In FDA Bacteriological Analytical Munual (Online).

Benjakul, S., Seymour, T. A., Morrissey, M. T., \& An, H. (1997). Physical and chemical changes in Pacific whiting muscle protein during ice storage. Journal of Food Science, 62(4), 729733.

Bilgin, S., \& Degirmenci, A. (2019). Quality changes in reared, hot-smoked meagre (Argyrosomus regius Asso, 1801) during chill storage at $4 \pm 1{ }^{\circ} \mathrm{C}$. Journal of Food Science and Technology, 39(2), 507-514.
Egan, H., Kirk, R.S., \& Sawyer, R. (1981) . Pearson's Chemical Analysis of Food. London: Churchill Livingston.

Farid, F. B., Latifa, G. A., Nahid, M. N., \& Far Begum, M. (2014). Comparison of the changes in phisico-chemical characteristics of dry salted snake-head Shoal (Channa striatus Bloch, 1801) and Taki (Channa punctatus Bloch, 1793) at room temperature $\left(27-31{ }^{\circ} \mathrm{C}\right)$. Research Journal of Animal Veterinary and Fishery Sciences, 2 (9), 18-23.

Frangos, L., Pyrgotou, N., Giatrakou, V., Ntzimani, A., \& Savvaidis, I. N. (2010). Combined effects of salting, oregano oil and vacuum-packaging on the shelf-life of refrigerated trout fillets. Food Microbiology, 27(1), 115-121.

Fuentes, A., Fernández-Segovia, I., Barat, J. M., \& Serra, J.A. (2011). Influence of sodium replacement and packaging on quality and shelf life of smoked sea bass (Dicentrarchus labrax L.). LWT - Food Science and Technology, 44(4), 917923.

Ikutegbe, V., \& Sikoki, F. (2014). Microbiological and biochemical spoilage of smoke-dried fishes sold in west african open markets. Food Chemistry, 161(15), 332-336.

Koral, S., Tufan, B., Ščavničar, A., Kočar, D., Pompe, M., \& Köse, S. (2013). Investigation of the contents of biogenic amines and some food safety parameters of various commercially salted fish products. Food Control, 32(2), 597-606.

Kumar, P., \& Ganguly, S. (2014). Role of vacuum packaging in increasing shelf life in fish processing technology: A Review. Asian Journal of Bio Science, 09(1), 109112.

Latifa, G.A., Chakraborty, S.C., Begum, M., Farid, F.B., \& Nahid, M. N. (2014). Comparative study of quality-analysis of three different Bangladeshi smoke-dried lean fishes using salt and turmeric stored 
at refrigeration temperature $\left(4^{\circ} \mathrm{C}\right)$. American Journal of Food Science and Technology, 2(6), 209-215.

Lohalaksanadech, S., \& Sujarit, C. (2016). Impact of coating on quality change of salted fish during storage. The 4 th Sunandha Academic National conference on "Research for sustainable development". 859- 866.

Lorentzen, G., Egeness, F. A., Pleym, I.E., \& Ytterstad, E. (2016). Shelf life of packaged loins of dried salt-cured cod (Gadus morhua L.) stored at elevated temperatures. Food Control, 64, 65-69.

Lorentzen, G., Wesmajervi Breiland, M.S., Østli, J., Wang-Andersen, J., \& Olsen, R.L. (2015). Growth of halophilic microorganisms and histamine content in dried salt-cured cod (Gadus morhua L.) stored at elevated temperature. $L W T$ Food Science and Technology, 60(1), 598-602.

Magnus, A., \& Turid, M. (2012). Brines added sodium bicarbonate improve liquid retention and sensory attributes of lightly salted Atlantic cod. LWT - Food Science and Technology, 46, 196-202.

Manthey, M., Karnop, G., \& Rehbein, H. (1988). Quality changes of European catfish (Silurus glanis) from warm water aquaculture during storage in ice. International Journal of Food Science \& Technology, 23(1), 1-9.

Masniyom, P. (2011). Deterioration and shelf-life extention of fish and fishery products by modified atmosphere packaging. Songklanakarin Journal of Science and Technology. 33(2). 181-192.

Mohan, C. O., Ravishankar, C. N., Srinivasa, T. K., Ashok, K. K., \& Lalitha, K. V. (2009). Biogenic amines formation in seer fish (Scomberomorus commerson) steak packed with $\mathrm{O}_{2}$ scavenger during chilled storage. Food Research International, 42(3), 411-416.
Nuwanthi, S. G. L. I., Madage, S. S. K., Hewajulige, I. G. N., \& Wijesekera, R. G. S. (2016). Comparative study on organoleptic, microbiological and chemical qualities of dried fish, goldstripe sardinella (Sardinella Gibbosa) with low salt levels and spices. Procedia Food Science, 6, 356-361.

Oyarekua, M. A. (2014). The effect of different processing methods on the nutritional quality and microbiological status of cat fish (Clarias lezera). Journal of Food Processing \& Technology, 5(6), $1-7$.

Pinar, O. (2013). Effect of salting and packaging on liquid-smoked rainbow trout fillets during refrigerated storage. African Journal of Microbiology Research, 7(50), 5719-5725.

Renato, S. C., Geany, P. C., \& Ana Clarissa, S. P. (2012). Structure and function of food engineering; Oxygen scavengers: An approach on food preservation. (pp. 21-42). Oliver Kurelic.

Reza, S.A., Karmaker, S., Hasan, M., Roy, S., Hoque, R., \& Rahman, N. (2015). Effect of traditional fish processing methods on the proximate and microbiological characteristics of Laubuka dadiburjori during storage at room temperature. Journal of Fisheries and Aquatic Science, 10(4), 232-243.

Siang, N. C., \& Kim, L. L. (1992). Determination of trimethylamine oxide, trimethylamine and total volatile basic nitrogen by conway's micro-diffusion method. In: Laboratory Manual on Analytical Methods and Procedures for Fish and Fisheries Products (Miwa and $\mathrm{Ji}$, eds.) Southeast Asia Fisheries Development Center. B3.1-B 3.6.

Sukjuntra, J. (2014). Situation of food safety and consumer behavior toward salted fish in Yala province. Journal of Yala Rajabhat University, 9(1), 85-98. 
Thai industrial standards institute. (2006). Half dried fish )TIST $298 / 2006$. ( Department of Industry, Bangkok, Thailand.

Thai industrial standards institute. (2006). Salt fish (TISI 312/2006). Department of Industry, Bangkok, Thailand.

Venugopal, V. (2006). Seafood processing: adding value through quick freezing, retortable packaging and cook-chilling. CRC press.

\section{Acknowledgment}

This research was funded by Yala Rajabhat University 